\title{
The Risk and Strategies of Potato Production in Garut, Indonesia
}

\author{
Karissa Nurbudiati* and Eliana Wulandari \\ Department of Agribusiness, Faculty of Agriculture, Universitas Padjadjaran, Bandung, Indonesia \\ *Corresponding author: karissanurbudiati54@yahoo.com
}

\begin{abstract}
The fluctuation of potato production has been caused by production risk in on-farm sector. This research aims to identify the sources of production risk in potato production and analyze the strategies to overcome the production risk. This research was conducted at Cantigi Farmers' Group, which has been actively producing potato in Cikajang Sub-district, Garut Regency, West Java. The data were collected from all 35 members of the Cantigi Farmers' Group. This study used Z-Score and Value at Risk analyses. The results showed that the sources of potato production risk that occurred in the Cantigi Farmers' Group were pests, diseases, rainfall, seed quality, managerial ability and soil fertility. Mitigation strategies can be used to overcome the risk sources such as by using intercropping method, plant-based pesticides, natural enemies, proper water management and drainage. Preventive strategies can be used to overcome the risk sources such as by using plant-based pesticides, organic fertilizers, assistance from local extension agents, in collaboration with certified seed breeders in the surrounding area and attending the training of how to breed properly. The research on potato production risk in Cikajang Sub-district is very significant considering that, to the best of authors' knowledge, the analysis of potato production risks has not been conducted yet in this important area of potato producing. This study was conducted in a limited scope of variable, therefore, a further research of potato production risks is suggested to be performed in a wider variable scope.
\end{abstract}

Keywords: farmers' group; potato; production risks; value at risk; z-score

Cite this as: Nurbudiati, K., \& Wulandari, E. (2020). The Risk and Strategies of Potato Production in Garut, Indonesia. Caraka Tani: Journal of Sustainable Agriculture, 35(2), 191-202. doi: http://dx.doi.org/10.20961/ carakatani.v35i2.34072

\section{INTRODUCTION}

Indonesia is an agricultural country that is rich with agricultural resources. In general, the agricultural sector in Indonesia is divided into three sub-sectors, namely food, horticulture and plantations. Based on the contribution of the agricultural sector to Indonesia's Gross Domestic Product (GDP), the horticultural sub-sector has an average growth rate of $2.81 \%$ (Ministry of Agriculture, 2017).

As an agricultural country with tropical climate, Indonesia is prospective for a horticultural business. The market of horticultural products in the future will be greater, both in the domestic and international markets (Irawan, 2003). Potato, as one of horticultural commodities, has been produced every year in Indonesia with different capacities. In 2014, potato production in Indonesia increased by $19.88 \%$, from $1,124,282$ tons to $1,347,818$ tons. However, the production of potato in the following year decreased. This can be caused by the challenges of developing potato such as competition with other horticultural commodities and the conversion of land for other uses (Rogi et al., 2016).

West Java Province is a center of potato production with a contribution of $24 \%$ or as much

\footnotetext{
* Received for publication August 20, 2019

Accepted after corrections March 4, 2020
} 
as 277,187 tons, then followed by Central Java Province with a contribution of $23 \%$ or as much as 269,476 tons (BPS-Statistics of Jawa Barat Province, 2018). One of the regencies in West Java, which is the center of potato production is Garut Regency (BPS-Statistics of Garut Regency, 2018). Cikajang Sub-district is one of the centers of potato production in Garut with an average potato production from 2011 to 2017 amounting to $30,565.3$ tons (BPS-Statistics of Garut Regency, 2018). One of the villages in Cikajang Sub-district that has the highest amount of potato production is Cikandang Village, with potato production in 2017 at 468.45 tons or around $14.98 \%$ of the total potato production in Cikajang Subdistrict (BPS-Statistics of Garut Regency, 2018). Cikandang Village is a highland of 1,310 meters above sea level with the majority of the main livelihood of the population as farmers and vegetable crop laborers, which is ecophysiologically suitable for horticultural commodity crop development areas (BPSStatistics of Garut Regency, 2018).

One of the farmers' groups that actively produce potato in Cikandang Village is Cantigi Farmers' Group. The Cantigi Farmers' Group produces potato varieties of Granola. However, the potato production was fluctuating. Potato production in the Cantigi Farmers' Group was still low compared to the potato production in Europe, which reached 25 tons per ha (Ministry of Agriculture, 2013). Based on the interviews with the head of the farmers' group, the production problems can be caused by many factors, for examples, pests and diseases, rainfall, managerial ability, soil fertility and seed quality.

Potato of Granola variety, such as those grown by farmers in the Cantigi Farmers' Group, is a variety that is sensitive to leaf blight (Phytophthora infestans). The research of Kusmana and Ambarwati (2018) showed that the level of damage caused by leaf blight on Granola variety was $84.4 \%$. The uncontrolled pest attacks can cause damage to potato crops and thus lead to crop failure (Somantri et al., 2016).

The research of Ishartati et al. (2019) revealed that the procurement and distribution of healthy and quality potato seeds are the problems in increasing potato productivity in Tosari, Pasuruan. Hirpa et al. (2010) confirmed that seed tuber quality is important because seed tubers ability to produce healthy and vigorous plants that produce high quality is limited by the growing season, in which the seeds will be used. Farmers in developing countries such as Indonesia usually use fourth or older generation seeds. Even though the longer generation of potatoes is used, the possibility of a decrease in quality is greater to occur (Mulyono et al., 2017).

The realization of a sustainable potato subsector in developing countries depends on the measures to overcome the number of risks that occur continuously, for instance, to reduce the accumulation of heavy metals in the soil, switching the use of chemical fertilizers to organic fertilizers is performed (Manurung et al., 2018). Therefore, appropriate production risk management is needed as a revitalization of agriculture towards sustainable agriculture.

The fluctuation of potato production faced by the Cantigi Farmers' Group can be because of the production risk in the on-farm sector. An empirical study of Ali and Kapoor (2008) has shown that in general, production risk is considered the most important source of risk in vegetable production. The purpose of this research is to identify the sources of production risk in potato cultivation and analyze strategies to overcome the risk of production. The research on the risk of potato production in Cikajang Subdistrict is very important considering the analysis of production risk of potato has not been conducted yet in Cikajang Sub-district as the important area for potato production.

\section{MATERIALS AND METHOD}

This research was conducted from September 2018 to January 2019 at the Cantigi Farmers' Group, Cikajang Sub-district, Garut Regency with the consideration that Cikajang Sub-district is one of the centers of potato production in Garut. The Cantigi Farmers' Group is the eldest farmers' group in Cikandang Village, which has been facing a long-running agricultural risk. The data were sourced from all members of the Cantigi Farmers' Group who cultivated potatoes in 2017. Since the total population of this study is less than 100 people, all of the population of the Cantigi Farmers' Group as many as 35 farmers were taken. Variables used in this study include the characteristics of farmers, production inputs, identification of sources of production risk and output of commodity production of potato. 
Data analysis in this study used Z-Score and risk impact analysis was performed with the Value at Risk (VaR) method. After that, risk mapping was carried out and risk handling strategies were determined. Z-Score was used to determine the likelihood of risk, while VaR was used to measure the impact of risks. After that, the results were placed into risk mapping as a description of the risk position on a map with two axes in between, in which the horizontal axis represents the risk impact, while the vertical axis represents the likelihood of risk occurring. The results of the risk mapping can be seen as the most effective risk management strategy.

According to Kountur (2008) analysis of data to calculate the possibility of the occurrence of risk using the Z-Score method is divided into several parts of calculation as follows:

\section{Possible production risks}

a. Calculating the average of risk event

$$
\bar{x}=\frac{\sum_{i=1}^{n} x_{i}}{n}
$$

b. Calculating the standard deviation value from risky events

$$
S=\sqrt{\frac{\sum_{1=1}^{n}(x i-\bar{x})^{2}}{n}}
$$

c. Calculating Z-Score value

$$
Z=\frac{X-\bar{x}}{S}
$$

\section{Risk impact calculating}

This calculation was carried out to measure how much loss in rupiah (IDR) the risk occurring in the production of potato. According to Kountur (2008), VaR can be calculated as follows:

$$
V a R=\bar{X}+\mathrm{Z}\left(\frac{S}{\sqrt{n}}\right)
$$

Where:

$\bar{x}=$ The average value of risky events

$x_{i}=$ Value of failure/farmer from risky events

$n=$ Number of farmers (35)

$S=$ Standard deviation of risky events

$Z \quad=$ Z-Score value of risky events

$\bar{X}=$ Risk limits that are considered to be still in the normal level by farmers

$V a R=$ The impact of losses caused by the risk event (IDR)

$\bar{X}=$ The average value of losses due to risk event

$\mathrm{Z}=\mathrm{Z}$ value from the normal distribution table with alpha 5\% due to the risk event (1.645)

\section{Risk mapping}

Risk mapping is an overview regarding the position of a risk in a map with two axes, namely horizontal axis describing the impact of risk and vertical axis describing the possibility of risk (Kountur, 2008). After all the risks, the risk possibility and the impact of the risk had been measured, the risk mapping was created as shown Figure 1 (Kountur, 2008).

Risk mapping is divided into four quadrants. Quadrant I is placed for the risks that have high possibility with low impact. Quadrant II is placed for the risks that have high possibility and high impact. Quadrant III is placed for the risks that have low possibility and low impact. Quadrant IV is placed for the risks that have low possibility and high impact.

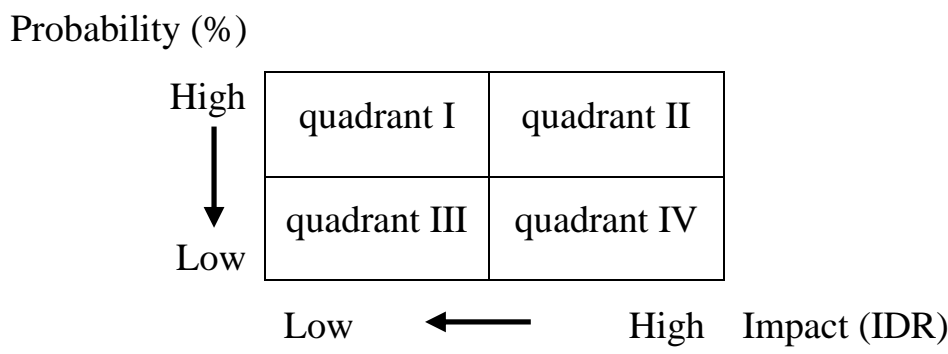

Figure 1. Risk map 


\section{Risk handling strategy}

\section{a. Preventive strategies}

Preventive strategies are used to deal with risks that are likely to be large, namely risks that are in quadrants I and II. When using a preventive strategy, the risks found in quadrant I will shift to quadrant III and the risks found in quadrant II will shift to quadrant IV (Kountur, 2008).

\section{b. Mitigation strategies}

Mitigation strategies are used to minimize the impact of risks that arise. Mitigation strategies are recommended for risks that are in quadrant II and IV which have a large risk impact. Risks that are in quadrant II and IV can be handled by means of mitigation strategies. Quadrant II shifts to quadrant I and quadrant IV shifts to quadrant III (Kountur, 2008).

\section{RESULTS AND DISCUSSION}

\section{The characteristics of respondents}

All the respondents of this study were male with an average age of 46 years and the majority of farmers have been cultivating potatoes for 11 to 20 years. The majority of farmers $(45.7 \%)$ have educational background of primary school. Age and level of education can affect the technology adoption of potato farming (Purba et al., 2014). With regard to the cultivation of potato, the members of Cantigi Farmers' Group cultivated potato without considering the growing season. This was due to the capital ownership by the farmers and the availability of potato seeds. Potato production in the Cantigi Farmers' Group in 2017 amounted to 239.90 tons with cultivated land areas of 11.52 ha.

Potato is the most important crop in the world because of the high nutritional value, however, the cultivation of potato plants in untreated land can result in low and poor quality of yields (Machuca et al., 2015). The production of the farmers of the Cantigi Farmers' Group in 2017 fluctuated and did not meet the production standards, and this was due to the risk of production in the on-farm sector. The technology used by the farmers of Cantigi Farmers' Group was still limited, which could affect the process and yield of potato production. One of the technologies used in potato cultivation was plastic mulch. Planting potatoes traditionally in deforested land could give low yields and poor quality compared to those using plastics. The efficiency of crop production can be improved by using plastic mulch and row cover to modify root zone temperature and plant growth, in addition to reduce pest damage and increase production on cultivated plants (Machuca et al., 2015).

\section{Identification of risk sources}

Climate change is one of the risks that can affect the way of potato to grow and harvest (Knox et al., 2011). Based on the results of interviews with the chairman and members of the farmers' group, several sources of risk that caused loss of potato production during 2017 were identified. The following factors are risk sources that caused low potato production in the Cantigi Farmers' Group:

Rainfall

Based on the results of interviews, rainfall greatly affected the growth of potato plants. In 2017, the rainfall that occurred in Cikajang Subdistrict was 180 days with an average of 15 days per month. The amount of rainfall intensity in one year was $2,865 \mathrm{~mm}$ with an average of $238 \mathrm{~mm}$ per month. High rainfall occurred in JanuaryApril then continued in October-December.

High rainfall affected the quality of potato plants caused by excessive water logging on the land and excessive absorption of water by the soil. This puddle caused the tubers to rot in the soil. In addition, high rainfall could inhibit sunlight. The growth of potato tubers would be hampered if there was a lack of sunlight. The lack of intensity of sunlight would inhibit the photosynthesis process of potato plants, which would cause small tubers to form so that the amount of production decreased. Extreme weather events, such as high intensity rainfall, could damage potatoes. Water logging on the ground, especially in summer regions, can cause tubers to rot (van der Waals et al., 2013). More than a quarter of the potato production losses were resulted from extreme weather in South Africa (van der Waals et al., 2016).

Pests

Pests are disturbing organisms in the process of cultivating potato plants. The sources of production risk in cultivating potato in the Cantigi Farmers' Group were black cutworm (Agrotis ipsillon) and serpentine leaf-miner (Lyriomiza huidobrensis). Besides diseases, insect pests were the main problems in potato cultivation in Bangladesh (Nasif et al., 2018). This black 
cutworm can damage potato plants when they are young. The part of the potato plant attacked by this pest was the base of the plant stem. The bitten base of the stem will easily break and die. Leaf miner is a pest that attacks potato plants in the leaves. This pest is a type of leaf fly pest. Symptoms can be seen in potato leaves. The surface of the potato leaves that are attacked by leaf miner has small holes that will fuse and eventually the surface of the potato leaves dries. Then the leaves of potatoes that are attacked by the pests will have brown spots. Leaf miners and black cutworms had an impact on the decline in production experienced by farmers in the Cantigi Farmers' Group. This is in line with the study of Fariyanti et al. (2007) that the risk of potato production is affected by pests and diseases. Lologau research (2010) showed that leaf miners' attacks could result in the losses of potato production of 14.6-92.8\%. However, the most damaging potato pest in Modoinding Sub-district, South Minahasa Regency, North Sulawesi, was Empoasca spp while Liriomyza spp was in the fourth position (Bororing et al., 2015).

\section{Disease}

One of risk sources for potato farming in the Cantigi Farmers' Group is disease. The attacks of diseases affected the amount of the results of production in the Cantigi Farmers' Group. Diseases attacking potato plants included late blight, bacterial wilt, fusarium wilt and tuber rot. Late blight is caused by the pathogenic fungus Phytophthora infestans. Symptoms of potato plants that are affected by late blight are the appearance of blackish brown spots and a white mildew-appearing area along petioles. The pathogen Phytophthora infestans that causes late blight is a major disease that can cause failure of potato production. The loss of yield resulted by Phytophthora infestans can reach 47-100\% (Ambarwati, 2012).

Bacterial wilt is caused by Pseudomonas solanacearum bacterium. This bacterium is easily transmitted through infected groundwater and agricultural tools that are usually used by potato farmers to divide the seed bulbs. When the plants are attacked by bacterial wilt, the young leaves of the plants will die and the bottom of the leaf begins to yellow. Fusarium wilt is caused by Fusarium oxisporyum. Symptoms of potato plants that are attacked by fusarium wilt are rotten tubers that cause the plants to wither. Rotten tuber is caused by the fungi Erwinia solanii. When a potato plant is infected with rotten tuber, the leaves will roll and turn yellow, and then dry and wither. The part of the potato plant that is in the soil causes brown spots. The research of Soesanto et al. (2011) showed that the pathogen with the dominant population in potato fields in Purbalingga Regency was Ralstonia solanacearum, amounting to $71.6 \%$ and followed by Fusarium oxysporum, which was also found in potato fields owned by the members of the Cantigi Farmers' Group. Whereas in Ethiopia, leaf rot and bacterial wilt are the main causes of reduced potato yields (Demissie, 2019).

\section{Seed quality}

Seed quality is one of the most influential sources of risk in cultivating potato in the Cantigi Farmers' Group. Similarly, in China, the main obstacle in producing potatoes was the lack of high quality potato seeds (Jansky et al., 2009). The seeds used by the farmers in the Cantigi Farmers' Group were obtained from seed breeders from other areas. The quality of seeds obtained from these seed breeders was poor, so there were some potato plants that did not grow. In addition to getting potato seeds from seed breeders, farmers used potato seeds from the previous crops. The seeds planted by the farmers were up to the fifth generation. Farmers have experienced the decrease in the production of each generation seed potato. This is in line with the research that states that the longer the generation of potato seedlings are used, the lower the quality of potato seeds will be (Mulyono et al., 2017).

\section{Managerial ability}

Managerial ability is the ability of the members of farmers' group to carry out potato cultivation activities in accordance with the standard operating procedures. Managerial skills are seen from the experience of farmers in cultivating specific potato variety. The average experience of the Cantigi Farmers' Group in cultivating specific potato was 13 years. But in fact, the process of cultivating potato from the beginning of planting to harvest was assisted by paid farm laborers. The most important aspect in managing production is labor such as its managerial ability (Kurniati, 2012). The managerial ability of farmer in cultivating potatoes has not yet implemented the standard operating procedures, and thus, this becomes one source of production risk. On the other hand, 
experience will be a major contributor to good managerial skills in conducting potato cultivation activities to achieve good potato production (Nuthall, 2009).

Soil fertility

Reduced soil fertility is one of the environmental problems caused by the use of pesticides (Okonya and Kroschel, 2015). Soil fertility in Cikandang Village has decreased during the years, which may be comparable to the high use of pesticides (chemical drugs) used by the farmers. The use of these pesticides can increase the residue of contaminated chemicals in the soil. As a result, it will damage microorganisms and organisms that are very beneficial for the development and growth of cultivated potato plants so that the level of soil fertility on the land planted with potato decreases. This is in line with the study of Roidah (2013), that excessive use of chemical fertilizers and chemical pesticides has an impact on environmental quality such as reduced soil fertility. Whereas, continuous potato cultivation without the addition of adequate nutrition in the highlands of Kenya caused a rapid decline in soil fertility, which was a major obstacle in potato production (Muthoni and Nyomango, 2009).

\section{Analysis of possible production risks}

Analysis of possible production risk was performed to find out how many times the risk sources were likely to occur in the Cantigi Farmers' Group in 2017. The analysis used the data from interviews with farmers in the Cantigi Farmers' Group. In this study, the normal limit of losing potato production was determined based on farmers' perceptions. This is in accordance with the recommendations from Saragih et al. (2018), that the determination of normal limits is based on the perceptions of farmers. The result of calculating the possibility of production risk in the Cantigi Farmers' Group is presented in Table 1.

Table 1. The possible production risks in Cantigi Farmers' Group

\begin{tabular}{lcccccc}
\hline \multicolumn{1}{c}{$\begin{array}{c}\text { Risk source/ } \\
\text { calculation results }\end{array}$} & Pest & Disease & Rainfall & $\begin{array}{c}\text { Seed } \\
\text { quality }\end{array}$ & $\begin{array}{c}\text { Managerial } \\
\text { ability }\end{array}$ & $\begin{array}{c}\text { Soil } \\
\text { fertility }\end{array}$ \\
\hline Total & 13,375 & 13,619 & 10,243 & $7,434.5$ & 2,995 & $1,933.5$ \\
Average & 382.1 & 389.1 & 292.7 & 212.4 & 85.6 & 55.2 \\
Standard deviation & 325.5 & 371.7 & 409.5 & 194.8 & 75.3 & 50.4 \\
Normal limit & 382.3 & 374.5 & 268.6 & 114.6 & 18.4 & 7.9 \\
Z & 0.00 & -0.04 & -0.06 & -0.50 & -0.89 & -0.94 \\
Table Z value & 0.5000 & 0.5160 & 0.5239 & 0.6915 & 0.8124 & 0.8264 \\
Probability (\%) & 50.00 & 51.60 & 52.39 & 69.15 & 81.24 & 82.64 \\
\hline
\end{tabular}

The probabilities of each source found in the Cantigi Farmers' Group are presented in Table 1. The sources of risks, arranged from the factor with the largest to the smallest probability, are soil fertility $(82.64 \%)$, managerial ability $(81.24 \%)$, seed quality $(69.15 \%)$, rainfall $(52.39 \%)$, disease $(51.60 \%)$ and pests $(50 \%)$.

\section{Impact risk analysis}

The impact of production risk sources in the Cantigi Farmers' Group was analyzed using the VaR method. VaR shows the amount of potential loss from an event that can occur in a particular period with a certain tolerance level. The tolerance level or confidence level used in this analysis was $95 \%$, with 5\% error. The results of the analysis are presented in Table 2 .
Table 2. The impact of production risk sources in Cantigi Farmers' Group

\begin{tabular}{clc}
\hline No. & \multicolumn{1}{c}{ Source of risk } & Impact (IDR) \\
\hline 1. & Pest & $3,388,598$ \\
2. & Disease & $3,588,672$ \\
3. & Rainfall & $3,052,415$ \\
4. & Seed quality & $1,909,504$ \\
5. & Managerial ability & 781,114 \\
6. & Soil fertility & 508,274 \\
\hline
\end{tabular}

Table 2 demonstrates the amount of impacts of the sources of risks, from the largest to the smallest, which include IDR 3,588,672 (disease), IDR 3,388,598 (pest), IDR 3,052,415 (rainfall), IDR $1,909,504$ (seed quality), IDR 781,114 (managerial ability) and IDR 508,274 (soil fertility). 


\section{Risk mapping}

The activity that needs to be carried out before conducting risk mapping is risk measurement. Risk measurement results in risk status and risk maps (Kountur, 2008). Risk status describes the order of risks, from the riskiest to the least risky. Risk status is obtained from multiplication between possible production risk and impact risk. The status of risk will determine the main priorities in risk handling strategy. The status values and priority sources of production risk in the Cantigi Farmers' Group are presented in Table 3.

Table 3. Status of production risks

\begin{tabular}{clccc}
\hline No. & \multicolumn{1}{c}{ Source of risk } & Impact (IDR) & Probability (\%) & Status of risk (IDR) \\
\hline 1. & Pest & $3,388,598$ & 50.00 & $1,694,299$ \\
2. & Disease & $3,588,672$ & 51.60 & $1,851,754$ \\
3. & Rainfall & $3,052,415$ & 52.39 & $1,599,160$ \\
4. & Seed quality & $1,909,504$ & 69.15 & $1,320,422$ \\
5. & Managerial ability & 781,114 & 81.24 & 634,609 \\
6. & Soil fertility & 508,274 & 82.64 & 420,037 \\
\hline
\end{tabular}

Table 3 summarizes the risk level of the six sources of potato production risks in the Cantigi Farmers' Group. The highest risk status is disease, followed by pests, rainfall, seed quality, managerial ability and soil fertility. After identifying the status of the risk, mapping the risk was then carried out. The risk map shows the position of the risk source to determine the appropriate risk handling strategy.

In the risk map, there are four quadrants with two axes on the risk map, namely the vertical and horizontal axis. Vertical axis describes the possibility of a risk and the horizontal axis defines the impact of the event. Quadrant I and II are quadrants that have a high probability, while quadrants III and IV are quadrants that have a large impact (Kountur, 2008). The results of mapping of risk sources in potato production activities in the Cantigi Farmers' Group can be seen in Figure 2.

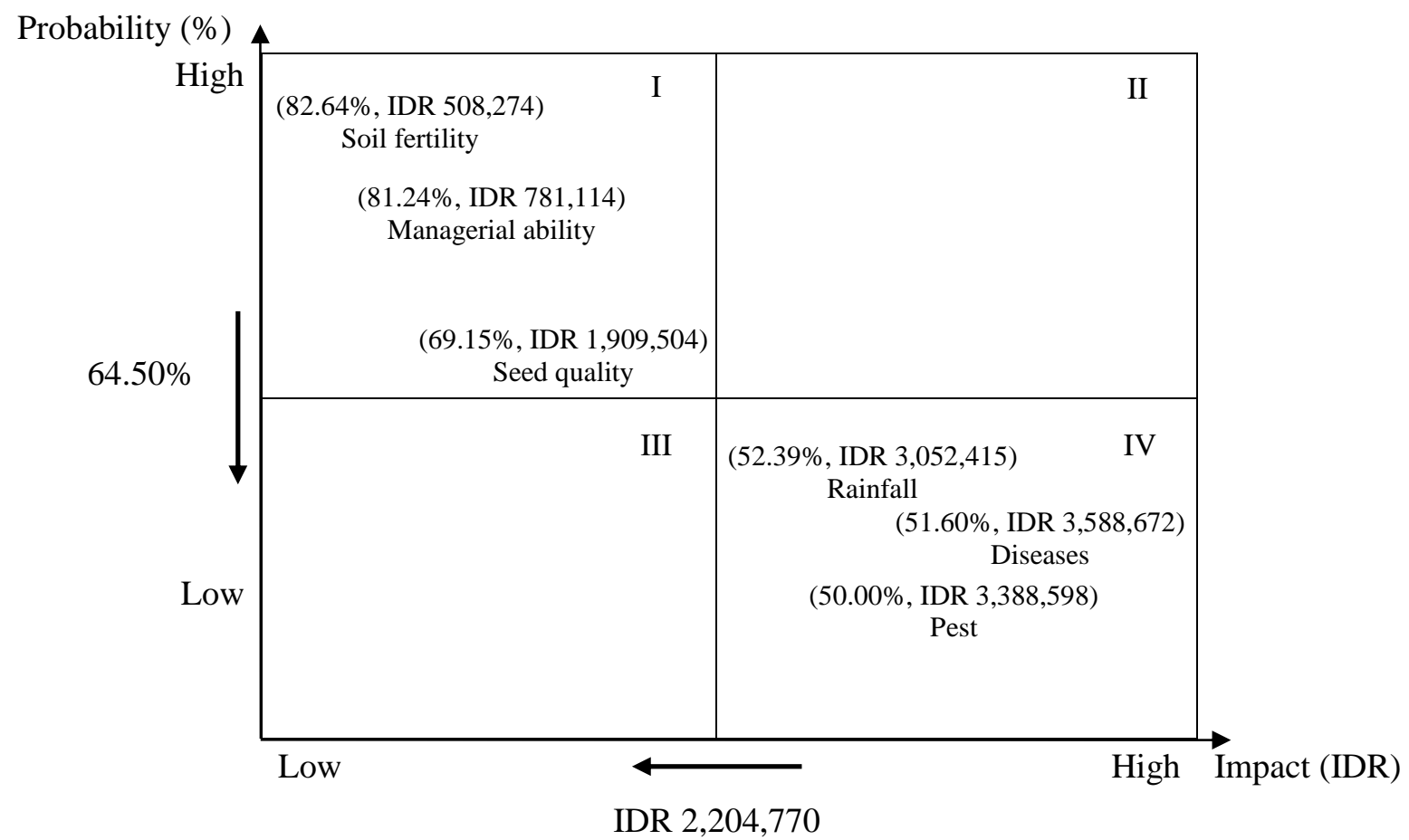

Figure 2. Production risk mapping 
The sources of risk for potato production in the Cantigi Farmers' Group are in quadrant I and IV. In this study, the extent of the possibility of risk and impact was determined based on the recommendations from the head of the farmer group, based on the average likelihood of occurrence of risk (probability) of $64.50 \%$ and the impact of IDR 2,204,770. This is in accordance with the recommendations of Kountur (2008), that the extent of the possibility of the occurrence of risks and the impact of these events is determined by management. Figure 2 shows that the possibility of risk from seed quality, managerial ability and soil fertility is greater than $64.50 \%$ with the impact of losses less than IDR 2,204,770, while the possibility of risk from for pests, diseases and rainfall is less than $64.50 \%$ with an impact of more than IDR 2,204,770.

\section{Handling strategy of potato production risk}

The keys to overcome the risks of climate change are skills, resources and knowledge to increase efficient production, to improve management and to apply new technology (Knox et al., 2011). In this research, preventive strategies were carried out for sources of risk of soil fertility, managerial ability and seed quality (quadrant I), while mitigation strategies were carried out for sources of risk of disease, rain and rainfall (quadrant IV).

\section{Preventive strategies}

Preventive strategies to deal with sources of risk of potato production in the Cantigi Farmers' Group include:

a. Soil fertility

Controlling soil fertility is one of the efforts to increase potato production (Nazari et al., 2012). The preventive strategy for the source of the risk of soil fertility, which was usually carried out by farmers of the Cantigi Farmers' Group, was plant rotating with plants that did not belong to one family with potato plants, for example cabbage and beans. Other preventive strategies was avoiding the excessive use of pesticides and beginning to use botanical pesticides (organic) and organic fertilizers. This is in line with the results of Hartatik et al. (2015) that organic fertilizers can improve soil fertility in physical, chemical and biological forms and increase crop production. b. Managerial ability

The managerial ability of farmers greatly determines the success in cultivating potato. Preventive strategies that were carried out to prevent human resource errors in conducting potato cultivation activities were the existence of socialization and mentoring from local extension workers regarding the Standard Operating Procedure (SOP) for potato cultivation.

c. Seed quality

The preventive strategy undertaken to prevent sources of risk of seed quality was the selection of seed breeder in accordance with the beliefs and experience of previous purchases. The Cantigi Farmers' Group cooperated with certified seed breeders in the surrounding areas. In addition, for nurseries from previous harvests, farmers should take part in trainings in potato breeding.

Mitigation strategies

Mitigation strategies to handle the risk source of potato production in the Cantigi Farmers' Group include:

\section{a. Diseases}

Diseases affecting potato plants in the Cantigi Farmers' Group were late blight, bacterial wilt, fusarium wilt and rotten tuber. The diseases were caused by fungi and bacteria. The mitigation strategy that was usually carried out by farmers in the Cantigi Farmers' Group was the use of intercropping patterns between potato plants with chili, cabbage, carrots and others plants. This was done to reduce the impact of losses if the production of potato crops was low due to disease attacks. However, in carrying out intercropping patterns, farmers should pay attention to what plants would be planted together with potato plants. Plants that would be intercropped were not plants originating from similar family with potato plants to avoid the life cycle of the disease on a land planted with potatoes.

In addition, the mitigation strategy carried out for the source of disease risk was biological disease control by using botanical pesticides and natural enemies. For potato plant disease, botanical pesticides used were from clover leaf plants, which were crushed into powder, then 
the powder was sprinkled and immersed into the soil. In addition, to control late blight in biology, the biological agent Trichoderma spp was used, with a dose of 100 grams 10 litres $^{-1}$ of water plus adhesive. Biological agent Trichoderma spp could inhibit the growth of aphids caused by the pathogenic fungus Phytophthora infestans. For fusarium wilt, biological control was carried out using biological agents Gliocladium sp. (Duriat et al., 2006).

b. Pests

Pests that attacked potato plants in the Cantigi Farmers' Group were black cutworms and leaf miners. The mitigation strategy usually applied by farmers in the Cantigi Farmers' Group was the use of intercropping between potato plants with chili, cabbage, carrots and other plants. This was done to reduce the impact of losses if the potato production was low due to pest attacks. Furthermore, the mitigation strategy for sources of risk for pests was biological pest control by using botanical pesticides and natural enemies. In general, vegetable pesticides used for diseases of potato plants came from neem leaves, galangal and lemongrass, which were mixed, mashed and soaked in 20 liters of water for 24 hours, then filtered and diluted with 60 liters of water (Duriat et al., 2006). The target of handling this mitigation strategy was to reduce the impact of production risk losses caused by pests.

c. Rainfall

Preventive measures against rainfall so as not to negatively affect agricultural production are difficult, but efforts to reduce negative impacts or mitigate rainfall can still be done. High rainfall causes many potato plants to die of decay. The mitigation strategies performed for sources of rainfall risk were the use of proper water management and the construction of good drainage channels so that rainwater did not flood the potato plants.

The results of handling preventive strategies for sources of risk for production of soil fertility, managerial ability and seed quality (quadrant I) have the potential to reduce the possibility of production risks, while the results of handling mitigation strategies for sources of risk of disease, pests and rainfall (quadrant IV) aim to minimize the impact of production risk losses. Figure 3 maps the risk sources after the handling strategy is carried out.

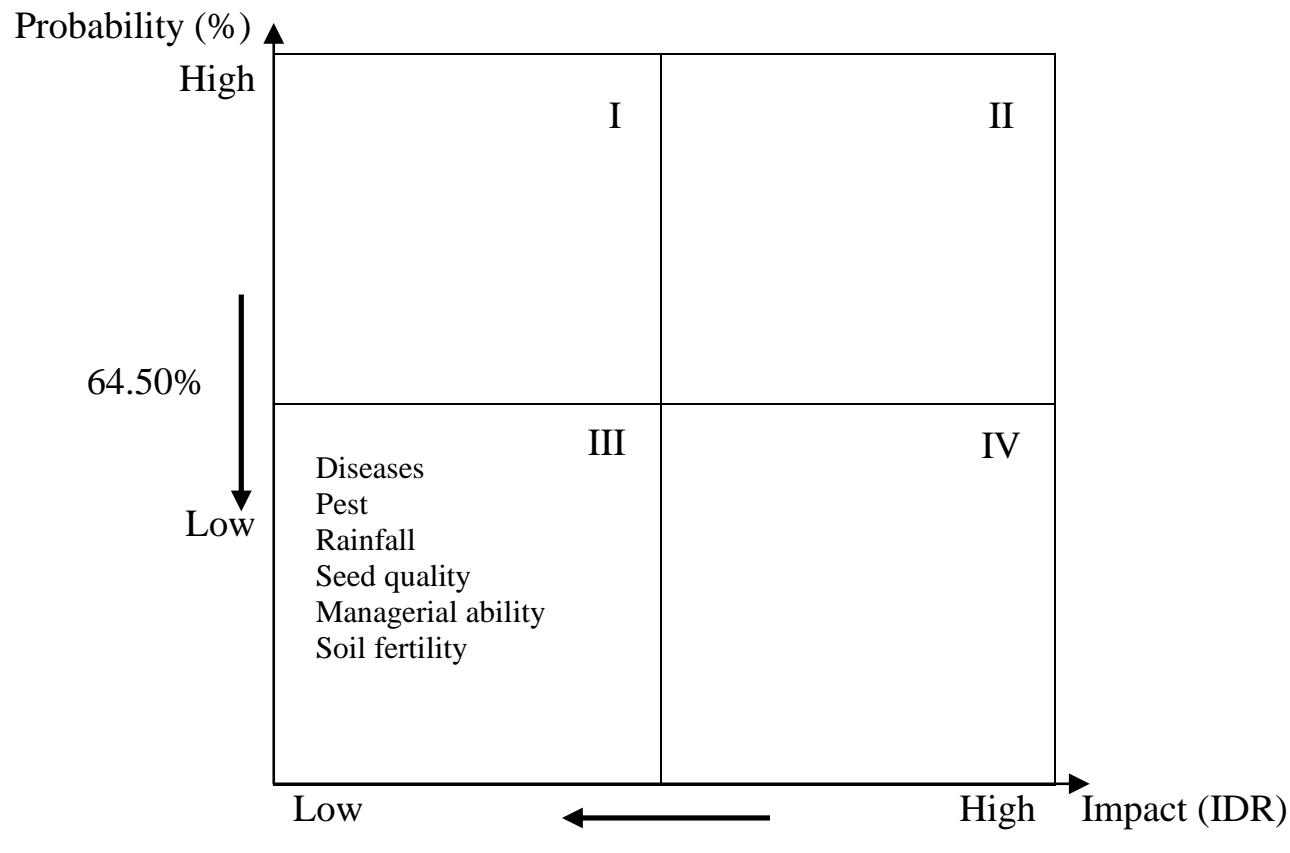

IDR 2,204,770

Figure 3. Map of risk sources after the handling strategy is performed 


\section{CONCLUSIONS}

Production risk sources in potato production activities of Cantigi Farmers' Group are diseases, pests, rainfall, seed quality, managerial abilities and soil fertility. Strategies to overcome the risks of diseases, pests and rainfall include intercropping, plant-based pesticides, natural enemies, proper water management and good drainage. The strategies in handling risk of seed quality, managerial ability and soil fertility include plant-based pesticides, organic fertilizers, and assistance on potato cultivation SOPs, cooperating with certified seed breeders, and proper farming training. The Cantigi Farmers' Group needs assistance from agricultural officer in handling pests and diseases, and to predict the right season of potato farming.

\section{REFERENCES}

Ali, J., \& Kapoor, S. (2008). Farmers' perception on risks in fruits and vegetables production: an empirical study of Uttar Pradesh. Agricultural Economics Research Review, 21, 317-326. https://doi.org/10.22004/ag.econ.47881

Ambarwati, A. D. (2012). Pemanfaatan tanaman kentang transgenik RB untuk perakitan kentang tahan penyakit hawar daun (Phytophthora infestans) di Indonesia. Jurnal Litbang Pertanian, 31(3), 94-102. Retrieved from http://ejurnal.litbang.pertanian.go.id/ind ex.php/ jppp/article/view/578

Bororing, A. R., Mahamit, J. M. E., Kandowangko, D. S., \& Wanta, N. N. (2015). Jenis dan populasi serangan hama yang berasosiasi pada tanaman kentang (Solanum tuberosum L) di Kecamatan Modoinding. COCOS, 6(6), 1-15. Retrieved from https:// ejournal.unsrat.ac.id/index.php/cocos/article/v iew/8041/7602

BPS-Statistics of Garut Regency. (2018). Garut Regency in figures 2018. Central Bureau Statistics of Garut Regency. Retrieved from https://garutkab.bps.go.id/publication/2018/08 /16/babad6984f1335b28ba9a7e6/kabupatengarut-dalam-angka-2018.html

BPS-Statistics of Jawa Barat Province. (2018). West Java Province in figures 2018. Central Bureau Statistics of West Java. Retrieved from https://jabar.bps.go.id/publication/2018/08/16 /d8b96de222796402938666e4/provinsi-jawabarat-dalam-angka-2018.html

Demissie, Y. T. (2019). Integrated potato (Solanum tuberosum L.) late blight (Phytophthora infestans) disease management in Ethiopia. American Journal of BioScience, 7(6), 123-130. https://doi.org/10.11648/j.aj bio. 20190706.16

Duriat, A. S., Gunawan, O. S., \& Gunaeni, N. (2006). Penerapan teknologi PHT pada tanaman kentang. Balai Penelitian Tanaman Sayuran. Retrieved from http://www.litbang. pertanian.go.id/ info-aktual/982/

Fariyanti, A., Kuntjoro, Hartoyo, S., \& Daryanto, A. (2007). Perilaku ekonomi rumah tangga petani sayuran pada kondisi risiko produksi dan harga di Kecamatan Pangalengan Kabupaten Bandung. Jurnal Agro Ekonomi, 25(2), 178-206. Retrieved from http://ejurnal. litbang.pertanian.go.id/index.php/jae/article/vi ew/4719/3985

Hartatik, W., Husnain, \& Widowati, L. R. (2015). Peranan pupuk organik dalam peningkatan produktivitas tanah dan tanaman. Jurnal Sumberdaya Lahan, 9(2), 107-120. Retrieved from http://ejurnal.litbang.pertanian.go.id/ind ex.php/jsl/article/view/6600/5859

Hirpa, A., Meuwissen, M. P. M., Tesfaye, A., Lommen, W. J. M., Oude Lansink, A., Tsegaye, A., \& Struik, P. C. (2010). Analysis of seed potato systems in Ethiopia. American Journal of Potato Research, 87(6), 537-552. https://doi.org/10.1007/s12230-010-9164-1

Irawan, B. (2003). Agribisnis hortikultura: peluang dan tantangan dalam era perdagangan bebas. SOCA: Jurnal Sosial Ekonomi Pertanian, 3(2), 1-22. Retrieved from https:// ojs.unud.ac.id/index.php/soca/article/view/40 29

Ishartati, E., Husen, S., Juliati, R., \& Santoko, A. (2019). Penerapan teknologi stek benih kentang pada kelompok tani Suka Makmur Desa Balendo-Tosari-Pasuruan. Conference on Innovation and Application of Science and Technology (CIASTECH 2019), 107-112. Retrieved from http://publishing-widyagama. ac.id/ejournal-v2/index.php/ciastech/article/vi ew/1159 
Jansky, S. H., Jin, L. P., Xie, K. Y., Xie, C. H., \& Spooner, D. M. (2009). Potato production and breeding in China. Potato Research, 52(1), 57. https://doi.org/10.1007/s11540-008-9121-2

Knox, J., Daccache, A., Weatherhead, K. \& Stalham, M. (2011). Climate change and potatoes: the risks, impacts and opportunities for UK potato production. Potato Council (AHDB) and Cranfield University. Retrieved from http://www.potato.org.uk/sites/default/ files/publication_upload/CCimpactspotatoes_ Final_20Sept2011.pdf

Kountur, R. (2008). Mudah memahami manajemen risiko perusahaan. Jakarta: PPM.

Kurniati, D. (2012). Analisis risiko produksi dan faktor-faktor yang mempengaruhinya dalam usahatani jagung (Zea mays L.) di Kecamatan Mempawah Hulu Kabupaten Landak. Jurnal Social Economic of Agriculture, 1(3), 60-68. Retrieved from http://jurnal.untan.ac.id/index .php/jsea/article/view/4366

Kusmana, \& Ambarwati, A. D. (2018). Evaluasi resistensi dan daya hasil enam klon harapan kentang transgenik terhadap serangan penyakit hawar daun. Jurnal Hortikultura, 28(1), 4150. Retrieved from http://ejurnal.litbang. pertanian.go.id/index.php/jhort/article/view/8 904

Lologau, B. A. (2010). Tingkat serangan lalat pengorok daun, Liriomyza huidobrensis (Blanchard) dan kehilangan hasil pada tanaman kentang. Prosiding Seminar Ilmiah Dan Pertemuan Tahunan PEI Dan PFI XX Komisariat Daerah Sulawesi Selatan, 358364.

Machuca, L. M. R., Jimenez, L. I., Aguilar, L. Al. V., Torres, V. R., Mendoza, A. B., \& De La Fuente, M. C. (2015). Cultivation of potato use of plastic mulch and row covers on soil temperature, growth, nutrient status, and yield. Acta Agriculturae Scandinavica, Section BSoil \& Plant Science, 65(1), 30-35. https:// doi.org/10.1080/09064710.2014.960888

Manurung, M., Setyo, Y., \& Suandewi, N. P. N. R. (2018). Akumulasi logam berat krom (Cr) pada tanaman kentang (Solanum tuberosum L.) akibat pemberian pestisida, pupuk organik dan kombinasinya. Jurnal Kimia, 12(2), 165172. Retrieved from https://ojs.unud.ac.id/ index.php/jchem/article/view/41201

Ministry of Agriculture. (2013). Outlook komoditi kentang. Pusat Data dan Sistem Informasi Pertanian. Retrieved from http://epublikasi. pertanian.go.id/arsip-outlook/261-outlookkomoditas-kentang-2013

Ministry of Agriculture. (2017). Laporan kontribusi PDB atas harga berlaku. Retrieved from aplikasi2.pertanian.go.id/pdb/rekappbd kontri.php

Mulyono, D., Syah, M. J. A., Sayekti, A. L., \& Hilman, Y. (2017). Kelas benih kentang (Solanum tuberosum L.) berdasarkan pertumbuhan, produksi, dan mutu produk. Jurnal Hortikultura, 27(2), 209-216. Retrieved from http://ejurnal.litbang.pertanian .go.id/index.php/jhort/article/ view/8103

Muthoni, J., \& Nyomango, D. O. (2009). A Review of constraints to ware irish potatoes production in Kenya. Journal of Horticulture and Forestry, 1(7), 098-102. Retrieved from https://academicjournals.org/journal/JHF/artic le-stat/6CA3E525108

Nasif, S. O., Sani, M. N. H., Islam, M. S., Touhidujjaman, M., Punam, K. F., \& Ali, M. R. (2018). A survey of potato growers in Bangladesh: production and challenges. Research in Agriculture Livestock and Fisheries, 5(2), 165-174. https://doi.org/10. 3329/ralf.v5i2.38054

Nazari, Y. A., Soemarno, \& Agustina, L. (2012). Pengelolaan kesuburan tanah pada pertanaman kentang dengan aplikasi pupuk organik dan anorganik. The Indonesian Green Technology Journal, 1(1), 7-12. Retrieved from https:// igtj.ub.ac.id/index.php/igtj/article/view/110

Nuthall, P. (2009). Modelling the origins of managerial ability in agricultural production. The Australian Journal of Agricultural and Resource Economics, 53(3), 413-436. https:// doi.org/10.1111/j.1467-8489.2009.00459.x

Okonya, J. S., \& Kroschel, J. (2015). A crosssectional study of pesticide use and knowledge of smallholder potato farmers in Uganda. BioMed Research International, 2015, 1-9. https://doi.org/10.1155/2015/759049

Purba, L., Lubis, S. N., \& Emalisa. (2014). Faktor - faktor sosial ekonomi yang mempengaruhi 
tingkat adopsi petani terhadap teknologi anjuran budidaya kentang (studi kasus: Kecamatan Merdeka, Kabupaten Karo, Propinsi Sumatera Utara). Journal on Social Economic of Agriculture and Agribusiness, 3(5), 1-14. Retrieved from https://jurnal.usu. ac.id/index.php/ceress/article/view/8204

Rogi, J. E. X., Kembuan, H. S. G., \& Rombang, J. A. (2016). Laju tumbuh umbi tanaman kentang varietas granola dan supejohn di dataran medium dengan pemulsaan. Jurnal Hortikultura Indonesia, 7(2), 83-90. Retrieved from https://journal.ipb.ac.id/index.php/jhi/ar ticle/view/15350

Roidah, I. S. (2013). Manfaat penggunaan pupuk organik untuk kesuburan tanah. Jurnal Universitas Tulungagung BONOROWO, 1(1), 30-42. Retrieved from http://jurnal-unita.org/ index.php/bonorowo/article/download/5/5

Saragih, I. R., Chalil, D., \& Ayu, S. F. (2018). Analisis risiko produksi padi dalam pengembangan asuransi usahatani padi (AUTP) (Desa Panca Arga, Kecamatan Rawang Panca Arga, Kabupaten Asahan). Jurnal Agrisep, 17(2), 187-196. Retrieved from https://ejournal.unib.ac.id/index.php/agri sep/article/view/4587

Soesanto, L., Mugiastuti, E., \& Rahayuniati, R. F.
(2011). Inventarisasi dan identifikasi patogen tular-tanah pada pertanaman kentang di Kabupaten Purbalingga. Jurnal Hortikultura, 21(3), 254-264. Retrieved from http://ejurnal. litbang.pertanian.go.id/index.php/jhort/article/ view/869

Somantri, R. U., Hidayanti, D., \& Syahri. (2016). Usahatani budidaya kentang di dataran tinggi Sumatera Selatan. Prosiding Seminar Nasional Membangun Pertanian Modern Dan Inovatif Berkelanjutan Dalam Rangka Mendukung MEA, 349-356. Retrieved from http://repository.pertanian.go.id/bitstream/han dle/123456789/6523/budidaya52.pdf?sequenc $\mathrm{e}=1$ \&isAllowed $=\mathrm{y}$

van der Waals, J. E., Kruger, K., Frankle, A. C., Haverkort, A. J., \& Steyn, J. M. (2013). Climate change and potato production in contrasting south african agro-ecosystems 3 . effects on relative development rates of selected pathogens and pests. Potato Research, 56(1), 67-84. https://doi.org/10.1007/s11540013-9230-4

van der Waals, J. E., Steyn, J. M., Frankle, A. C., \& Haverkort, A. J. (2016). Grower Perceptions of biotic and abiotic risks of potato production in South Africa. Crop Protection, 84, 44-55. https://doi.org/10.1016/j.cropro.2016.02.008 